\title{
An Archaeological Assessment for the San Antonio Municipal Stadium
}

I. Waynne Cox

Center for Archaeological Research

Guillermo I. Mendez

Center for Archaeological Research

Follow this and additional works at: https://scholarworks.sfasu.edu/ita

Part of the American Material Culture Commons, Archaeological Anthropology Commons, Environmental Studies Commons, Other American Studies Commons, Other Arts and Humanities Commons, Other History of Art, Architecture, and Archaeology Commons, and the United States History Commons

Tell us how this article helped you.

This Article is brought to you for free and open access by the Center for Regional Heritage Research at SFA ScholarWorks. It has been accepted for inclusion in Index of Texas Archaeology: Open Access Gray Literature from the Lone Star State by an authorized editor of SFA ScholarWorks. For more information, please contact cdsscholarworks@sfasu.edu. 


\section{An Archaeological Assessment for the San Antonio Municipal Stadium \\ Creative Commons License \\ (c) $($ ) $(9)$}

This work is licensed under a Creative Commons Attribution-NonCommercial 4.0 International License 


\section{AN ARCHAEOLOGICAL ASSESSMENT FOR THE SAN ANTONIO MUNICIPAL STADIUM}

I. Waynne Cox and Guillermo I. Mendez

Texas Antiquities Committee Permit No. 1272

Center for Archaeological Research

The University of Texas at San Antonio ${ }^{\circledR}$

Archaeological Survey Report, No. 226

1993 
The following information is provided in accordance with General Rules of Practice and procedure Chapter 41.11 (Investigation Reports), Texas Antiquities Committee.

1. Type of investigation: Archival study and survey with shovel tests.

2. Project name: Municipal Stadium Project.

3. County: Bexar.

4. Principal Investigator: Jack D. Eaton.

5. Name and location of sponsoring agency: Department of Parks and Recreation, City of San Antonio, San Antonio, Texas 78283-3966.

6. Texas Antiquities Committee Permit No. 1272.

7. Published by the Center for Archaeological Research, The University of Texas at San Antonio, San Antonio, Texas 78249-0658, 1993.

A list of publications by the Center for Archaeological Research can be obtained by sending $\$ 1.00$ to the Center for Archaeological Research, The University of Texas at San Antonio, San Antonio, Texas 78249-0658. 


\begin{abstract}
The Center for Archaeological Research, The University of Texas at San Antonio was contracted by the Parks and Recreation Department, City of San Antonio to conduct archival and survey testing on 43 acres of land in western San Antonio at Leon Creek prior to establishing a municipal baseball stadium. The past history of the site was investigated and a survey and shovel testing was conducted on July 8-9, 1993. No indications of archaeological resources were discovered, therefore, no further investigations were recommended.
\end{abstract}




\section{TABLE OF CONTENTS}

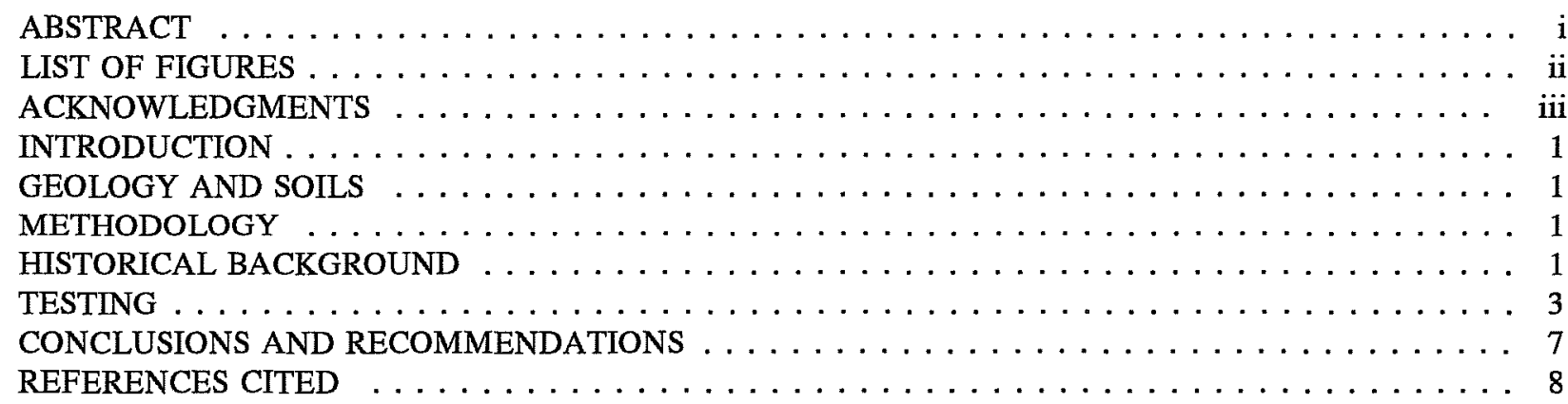

\section{LIST OF FIGURES}

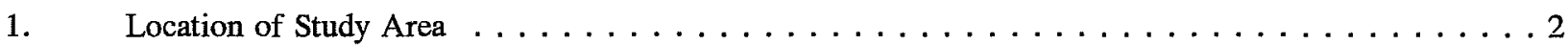

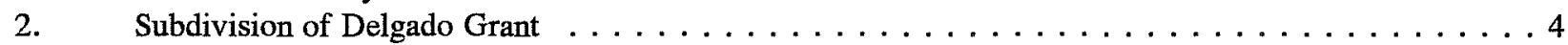

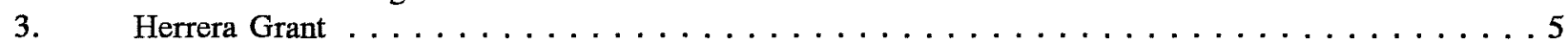

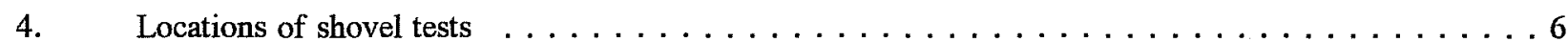




\section{ACKNOWLEDGMENTS}

The staff of the Center for Archaeological Research would again like to take this opportunity to express their appreciation to the Parks and Recreation Department, City of San Antonio, for permitting us to participate in this project. We especially wish to acknowledge the cooperation of Dale Bransford who greatly facilitated our work. 


\section{INTRODUCTION}

In June of 1993, Mr. Dale Bransford, Services Administrator for the Department of Parks and Recreation, City of San Antonio, requested that the Center for Archaeological Research, The University of Texas at San Antonio (CARUTSA) conduct an assessment of archaeological potential on 43 acres of land in western San Antonio. The tract of land at the northwest corner of the intersection of Highway 90 and Callaghan Road had been selected for development as the San Antonio Municipal Baseball Stadium. It was recommended that archival research be conducted to investigate the historical background of the property to be followed with an extensive walkover survey with shovel testing where appropriate. Jack D. Eaton, Acting Director of the CAR, served as Principal Investigator. The archival research was accomplished by Waynne Cox, Research Associate, and the fieldwork and testing was conducted by Guillermo Mendez, Technical Staff Assistant, on July 7 and 8, 1993.

\section{GEOLOGY AND SOILS}

The land in question is located in central Bexar County along the eastern margin of the old channel of Leon Creek. The floodplain within the property has been considerably altered by channelization and terracing to improve drainage. The soils are primarily of the Venus Loam series with a one to three percent slope (Figure 1). Soils of this type are typically deep, moderately dark colored and limy being created by washed terraces and alluvial fans. The surface soils are very dark grayish-brown to brown silty clay with an average depth of approximately 24 inches, with subsoils tending toward a brown silty clay. These tend to overlay a light yellowish-brown or pale brown clay to a depth of several feet. These soils begin to grade into Lewisville series dark clay loam toward the eastern margin of the site (Taylor et al. 1968:52).

\section{METHODOLOGY}

The archival investigation began with a recent deed chain of ownership furnished by the Parks and Recreation Department. This indicated that the location held no sites of historic significance from 1918 until the present. A search was then initiated beginning with the original land grant during the Republic of Texas period. The on site investigation was conducted by performing an extensive pedestrian survey of all accessible areas; those not under development nor too heavily covered with plant growth. After the survey 17 representative or suspect areas were selected for shovel testing. A review of the site files indicated no sites had previously been recorded. This lack of sites within the area may be largely do to the fact that over six landfills are recorded within a mile radius of the location under consideration.

\section{HISTORICAL BACKGROUND}

The area under investigation lies immediately outside the original eight leagues of land granted by the King of Spain, in 1734, as the limits of the Villa de San Fernando. During the Spanish period one of the defendants of the original settlers from the Canary Islands, Amador Delgado, established a ranch on the western bank of the Leon Creek seven miles from the small settlement (Jackson 1986:92). In 1836, when President General Santa Anna arrived to retaliate for the ousting of Mexican troops by the rebellious Texians, the Delgados fled to their ranch to avoid the battle that ensued at the Alamo fortress (Chabot 1937:173).

Soon after the battle of San Jacinto, David G. Burnet set in motion the machinery for a constitutional government. In September elections were held and Sam Houston was inaugurated as first President of the Republic. The new Republic was without a strong financial base and was pressed to find means of raising revenue without direct taxation, an idea totally repugnant to those on the frontier. The most expedient avenue open to them was to utilize the only resource that they possessed, and possessed in abundance - land. On December 12, 1837, the Congress enacted the General Land Act, providing for a general land office under the direction of the Commissioner General of the Land Office. The office was authorized to reward the citizens for their service by distribution of parcels of 


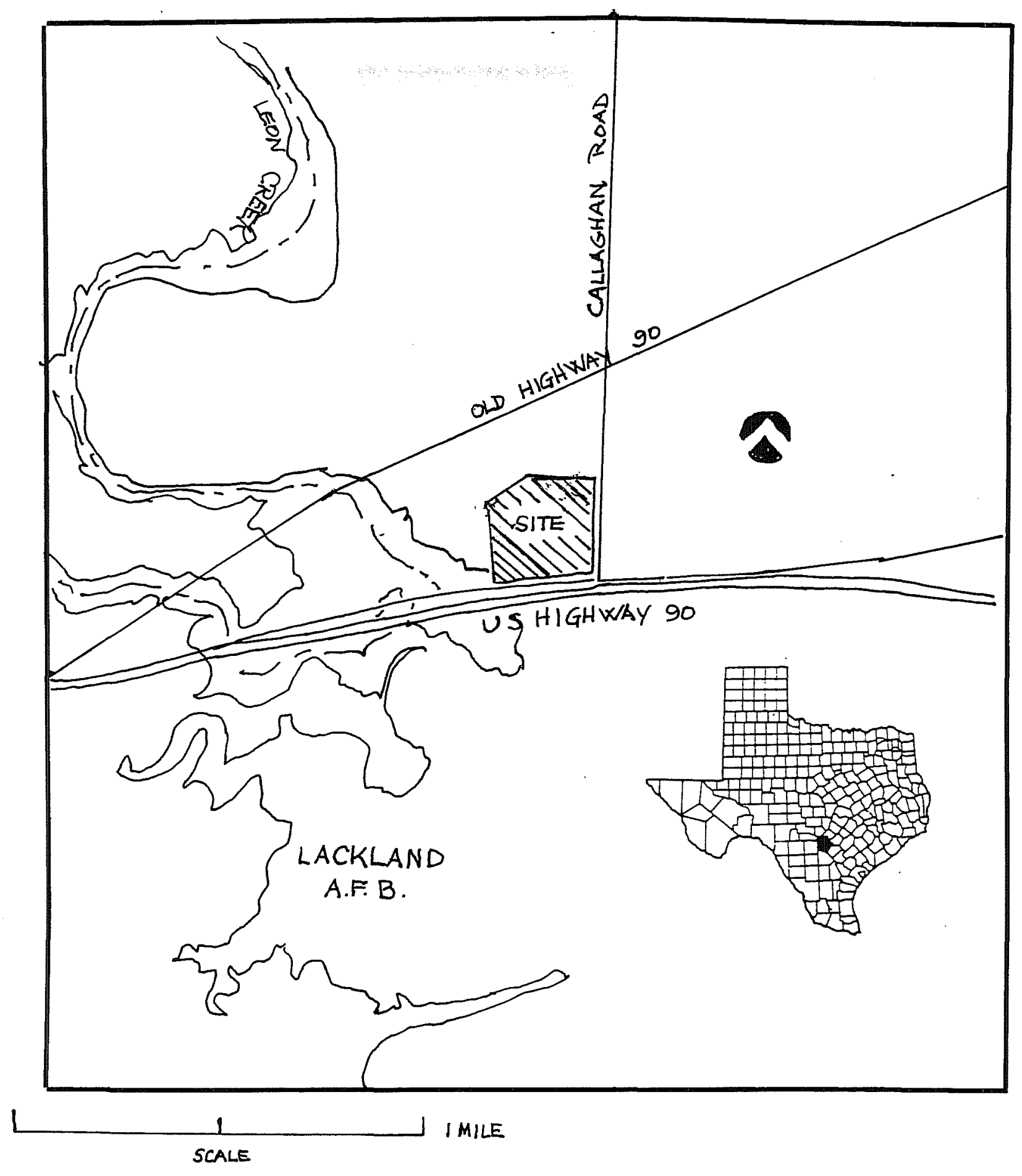

Figure 1. Location of study area. 
lands. Every person who had arrived in the Republic after the date of the declaration of independence but prior to October 1, 1837, and was head of a family, was entitled to a conditional grant of one thousand, two hundred and eighty acres, a First Class Land Certificate. All single men were to receive 640 acres under the same conditions of date of entry, these were designated Second Class Land Certificates (Strickland 1930:274-276). These became valid after the land was surveyed and the required fees paid, and these entitlements could be, and frequently were, transferred to another individual for a sum agreed upon by both parties. The Republic recognized title granted under both the Spanish and Mexican governments when they could be substantiated by the claimants. In the case of the Delgado lands Amador's son, José, posted a claim for a small portion of land on the east side of Leon Creek which was recognized by the Republic and a date of title of 1833 was authorized. In 1872 the Delgado property passed to the heirs of José Delgado; Nicolas Delgado, Tomasa de Jesus Casanova y Delgado, Casiana Delgado and Amador Delgado (Figure 2). The property was divided equally among them; Amador received the portion which contains the stadium property (Bexar County Deed Records [BCDR], Office of the County Clerk, Deed Records Office, Heritage Plaza Building, San Antonio, Texas W1:565). Amador conveyed some portion of the property to various purchasers, but at the time of his death in 1925 he was still residing on the property at 658 Callaghan Road (Chabot 1937:173).

The larger grant of a League and Labor surrounding the Delgado lands was authorized and bestowed upon Rafael Herrera. In 1830 a census listed Rafael Herrera as residing in Bexar, married to Vicenta Curbier with one son, Manuel, age one year (White 1986:92). Herrera conveyed his right to the land to Nathaniel Lewis, who had the tract surveyed as Survey No. 74, on August 15, 1838 (Bexar County Survey Book A1:89, Bexar County Archives, Heritage Plaza Building, San Antonio, Texas) (Figure 3).

Nathaniel Lewis was born June 11, 1806 in Falmouth, Massachusetts and ran away to sea at an early age. After several misadventures he was stranded on the coast of Texas at Indianola in 1830, where he established a mercantile business. He soon relocated to San Antonio where he opened a store and mill (Webb 1952:II:53). At the beginning of the Republic period he began to amass land grants and established two of the largest ranches in Texas, one comprised almost half of present Camp Bullis Military Reservation and the other centered along the Leon Creek, including the land of the present survey. Lewis died October 21, 1872 in San Antonio, one of the wealthiest men of the state. As his obituary stated: "He was never what is called a public spirited [emphasis in original] man, and yet has always exercised more or less of influence over public affairs." The article further stated that at the time of his death that he had disposed of "his live stock interest, which was one of the largest in Western Texas" (San Antonio Express, 23 October, 1872). While he may have disposed of his cattle, the Leon Creek Ranch remained intact and passed to his widow and second wife, Mary Fannie Liffering Lewis. His son, Nathaniel Jr., later took his mother to court to gain a division of the property and was awarded the southern portion of the ranch below "the Castroville Road" (US Highway 90), while the remainder of the ranch and the Bullis property was awarded to Mary and her younger son, Daniel. Daniel sold his portion of the "old Lewis Ranch" to Philander L. Cable, of Rock Island, Illinois, for \$17,439 in April of 1886 (BCDR 33:552). Cable died in Bexar County on May 21, 1886, and the property passed to his widow Mary J. Cable, who transferred it to her children Ben T. and Lucie R. Cable Castleman (BCDR 101:420).

\section{TESTING}

The pedestrian survey was conducted on July 8, 1993 with no overt indication of any archaeological sites detected. The area was then studied with the intent of selecting specific areas which appeared to be undisturbed for shovel testing. A series of four datum points were established and from these 17 shovel tests were located and excavated (Figure 4). In shovel test one the top 4 inches consisted of a hard packed light gray soil, from 4 inches to 12 inches the soil changed to a tan color with small pebbles that appeared to consist of fill material. The second test unit was chosen because of the presence of small chert cobbles, none of which gave any indication of having been altered. The soil again was light gray in color to a depth of about 2 inches. At a depth of 2 inches to 12 inches the soil was tan with small pebbles; at 12 inches concrete was encountered confirming that the area had been filled. Testing continued in this manner until 17 test units were excavated; no indication of any cultural resources were located (Figure 4). Testing was concluded on July 9, 1993. 

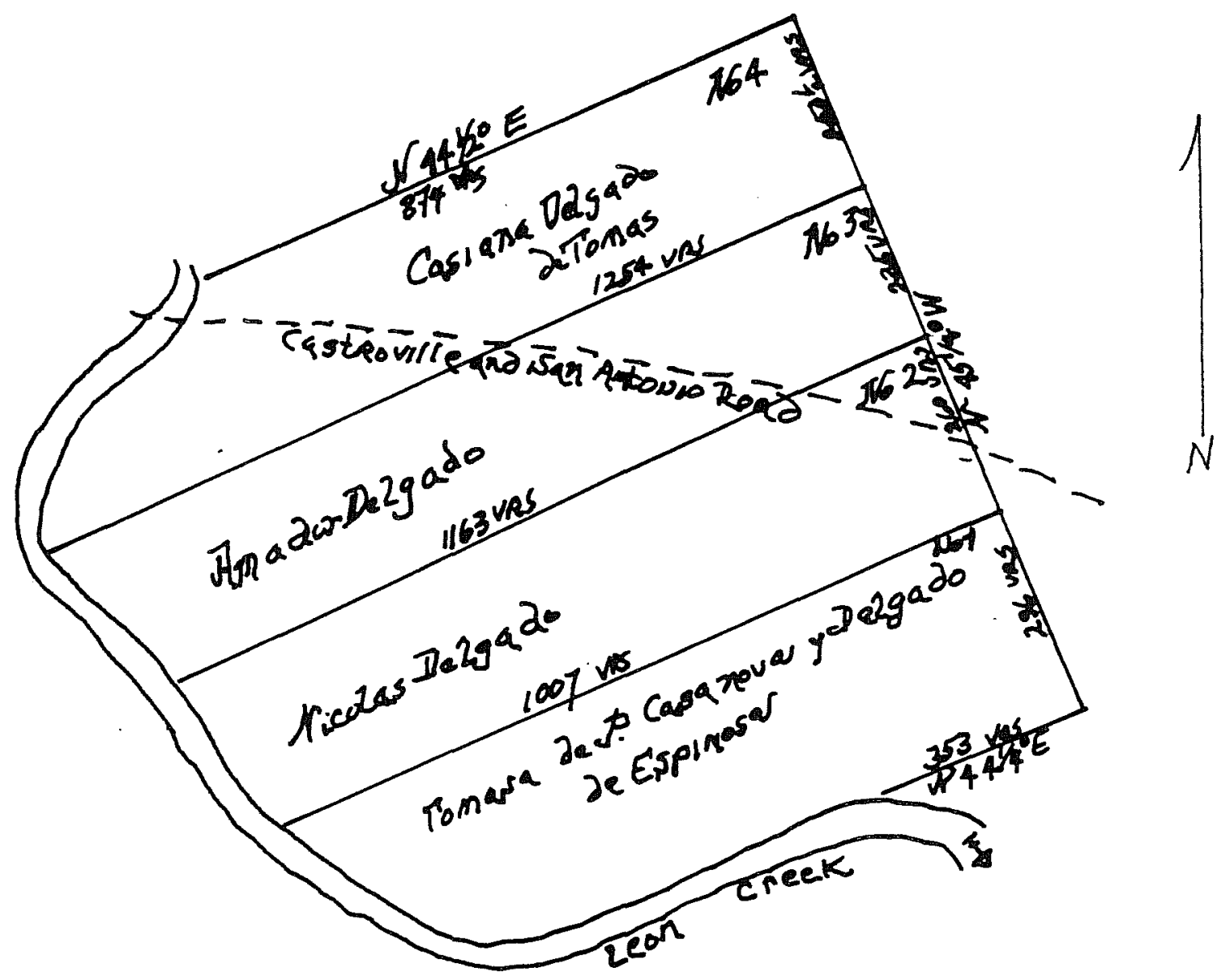

Figure 2. Subdivision of Delgado Grant, adapted from original plat, not to scale. 


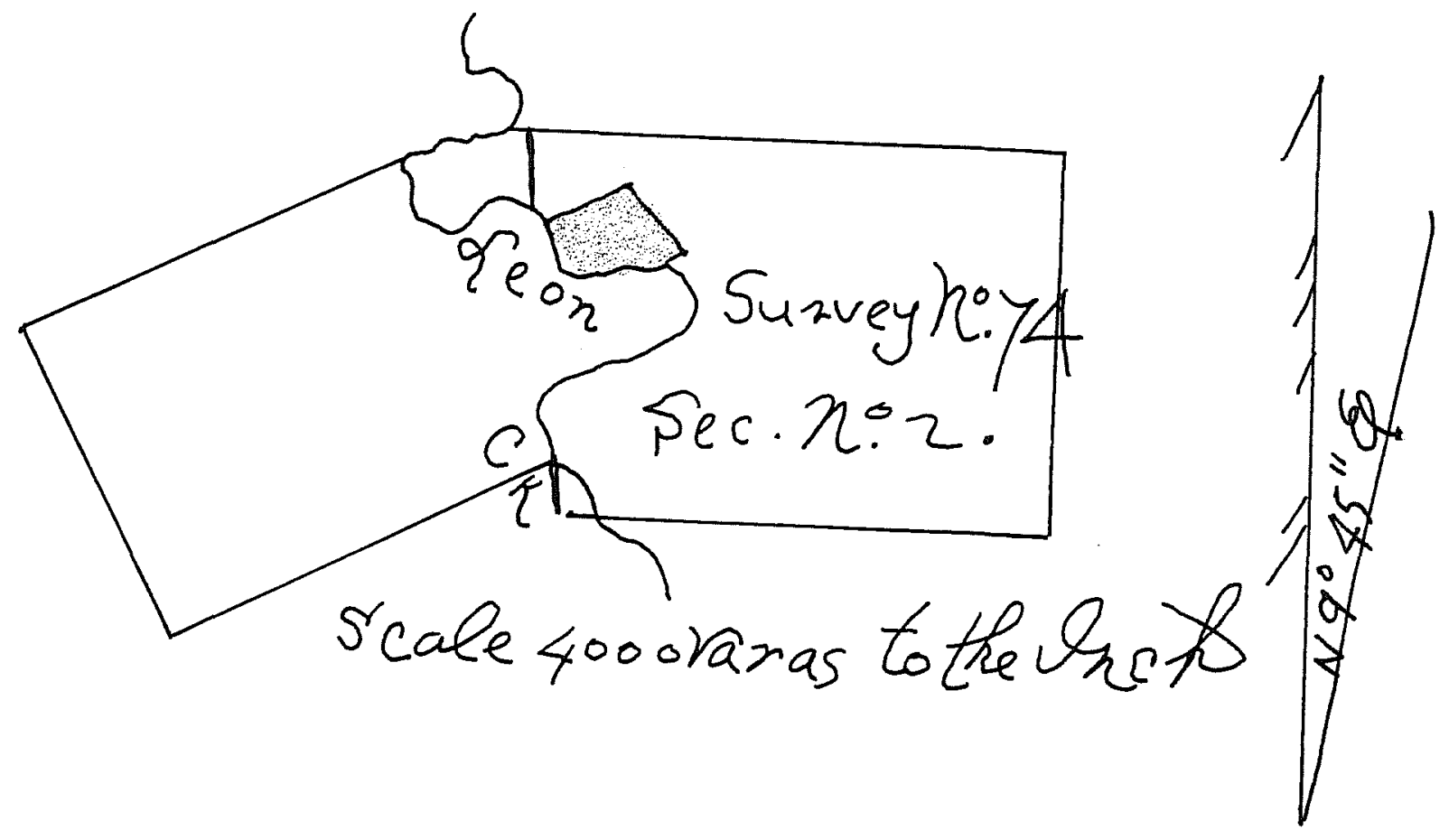

Figure 3. Herrera Grant, acquired by Lewis and surveyed as Survey No. 74. Adapted from original plat, not to scale. Shaded area is the Delgado Grant. 


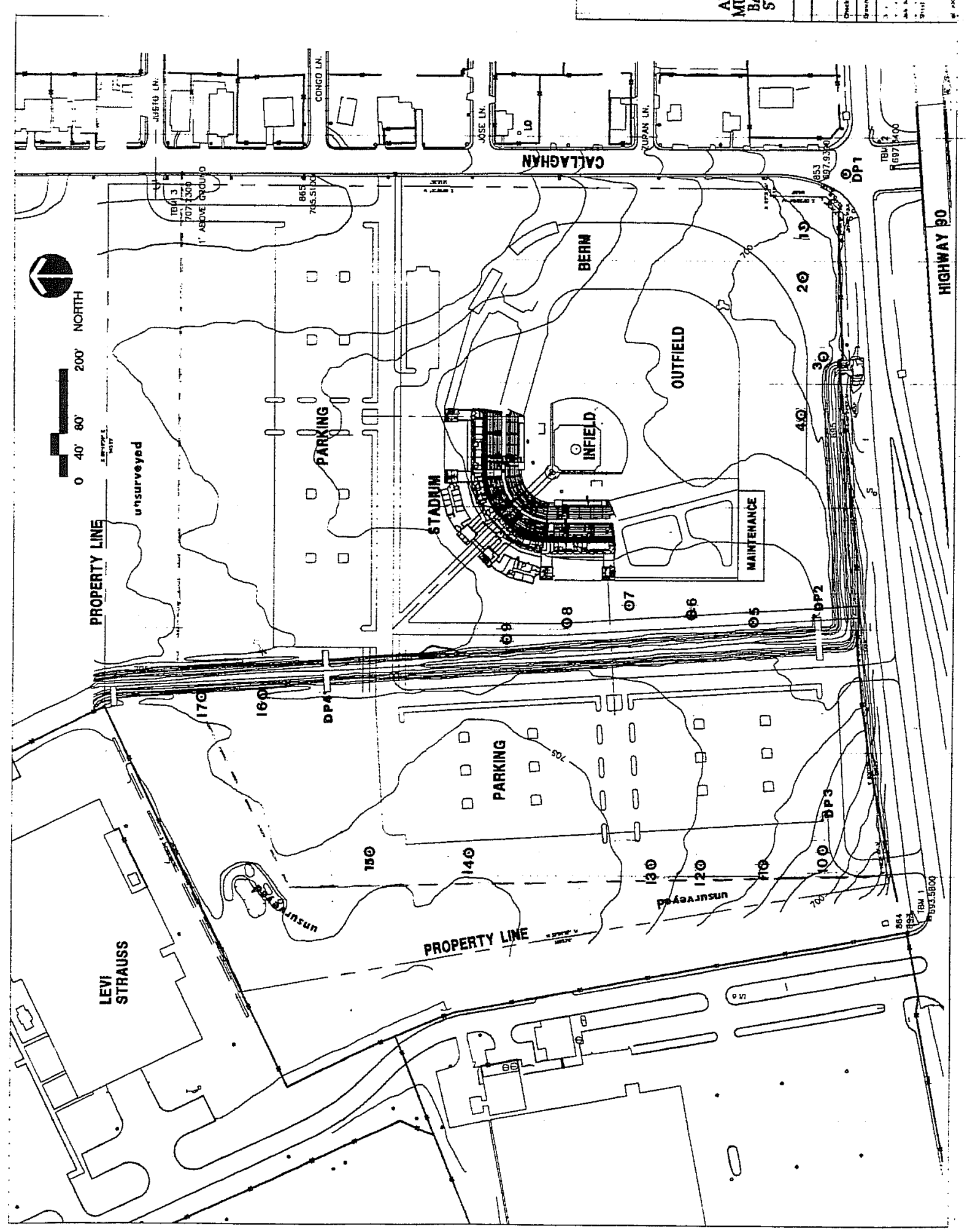

Figure 4. Locations of shovel tests. 


\section{CONCLUSIONS AND RECOMMENDATIONS}

Neither archival research nor testing give any indication that the area contains significant archaeological resources. The historic record indicates that the probability of historic structural remains is remote. The tests indicate that the area was seriously altered by previous episodes of landfill and drainage work. No further work is recommended at this location. 


\section{REFERENCES CITED}

Chabot, F. C.

1937 With the Makers of San Antonio. Artes Graficas, San Antonio.

Jackson, J.

1986 Los Mesteños: Spanish Ranching in Texas, 1721-1821. Texas A and M Press, College Station.

San Antonio Express

1872 "Died." 23 October. San Antonio.

Webb, W. P. (editor)

1952 The Handbook of Texas, vol. II. The Texas State Historical Association, Austin.

White, G.

19861830 Citizens of Texas. Eakin Press, Austin.

Strickland, R. W.

1930 History of Fannin County, Texas, 1836-1843. Southwestern Historical Quarterly 33:262-298.

Taylor, F. B., R. B. Hailey, and D. L. Richmond

1968 Soil Survey of Bexar County, Texas, Series 1962, No. 12. United States Department of Agriculture, Soil Conservation Service. 


